\title{
PENERAPAN MODEL PEMBELAJARAN OSBORN UNTUK ME- NINGKATKAN LITERASI MATEMATIS SISWA SMP
}

\section{Milla Mustikawati Sugandi}

\section{Politeknik Kridatama Bandung}

email korespondensi: millamustikawatisugandi@gmail.com

\section{RIWAYAT ARTIKEL}

Diterima (24-11-2019)

Revisi (04-12-2019)

Diterbitkan(30-12-2019)

\begin{abstract}
ABSTRAK
Penelitian ini dilatarbelakangi oleh kenyataan masih rendahnya literasi matematis siswa, padahal kemampuan ini merupakan tujuan pelajaran matematika. Oleh karena itu, diperlukan suatu strategi untuk mendorong siswa dalam mengembangkan literasi matematisnya. Pembelajaran dengan model Osborn memungkinkan siswa untuk mengembangkan literasi matematis karena pembelajaran dilakukan secara interaktif. Tujuan penelitian ini adalah untuk mendeskripsikan serta menelaah peningkatan literasi matematis siswa yang mendapat model pembelajaran Osborn dan siswa yang mendapat pembelajaran ekspositori. Penelitian ini merupakan penelitian kuasi eksperimen dengan sampel penelitian dua kelas dari kelas VIII SMP pada salah satu sekolah di Kota Cimahi. Satu kelas dipilih sebagai kelompok kontrol mendapatkan pembelajaran ekspositori dan satu kelas lainnya sebagai kelompok eksperimen mendapatkan model pembelajaran Osborn. Instrumen yang digunakan untuk mengumpulkan data pada penelitian ini terdiri dari instrumen tesdan non tes. Data yang diperoleh dianalisis secara kuantitatif, data tersebut dianalisis menggunakan uji statistik t. Hasil penelitian menyimpulkan bahwa,peningkatan kemampuan literasi matematis siswa yang mendapatkan model pembelajaran Osborn lebih baik daripada siswa yang mendapat pembelajaran ekspositori. Hasil penelitian menunjukkan literasi matematis siswa yang diajarkan dengan menggunakan model pembelajaran Osborn lebih baik dari pembelajaran ekspositori. Dengan demikian, hasil penelitian ini berimplikasi terhadap pemilihan model pembelajaran oleh guru matematika di sekolah.
\end{abstract}

Kata kunci: literasi matematis, metode ekspositori, model pembelajaran Osborn 


\begin{abstract}
This research is motivated by the fact that students' mathematical literacy is still low, even though this ability is the goal of mathematics. Therefore, we need a strategy to encourage students to develop their mathematical literacy. Learning with the Osborn model allows students to develop mathematical literacy because learning is done interactively. The purpose of this study was to describe and examine the increase in mathematical literacy of students who received the Osborn learning model and students who received expository learning. This research is a quasi-experimental research with a sample of two classes from class VIII of junior high school in one of the schools in Cimahi City. One class was chosen as a control group to get expository learning and another class as an experimental group to get Osborn's learning model. The instrument used to collect data in this study consisted of test and non-test instruments. The data obtained were analyzed quantitatively, the data were analyzed using a statistical test $t$. The results of the study concluded that, increasing the mathematical literacy ability of students who got the Osborn learning model was better than students who got expository learning. The results showed the mathematical literacy of students taught by using the Osborn learning model was better than expository learning. Thus, the results of this study have implications for the selection of learning models by mathematics teachers in schools.

Key words: expository method, mathematical literacy, Osborn learning model.
\end{abstract}

\title{
1. Pendahuluan
}

Kemajuan ilmu pengetahuan dan teknologi dewasa ini berkembang sangat pesat.Hal ini mengakibatkan sumber informasi dapat diperoleh dengan mudah dan relatif singkat.Arah kemajuan teknologi ditentukan oleh kualitas sumber daya manusia, oleh sebab itu pembangunan sumber daya manusia (SDM) harus diutamakan. Salah satu cara agar setiap individu memiliki pengetahuan, wawasan, dan keterampilan, adalah melalui pendidikan. Berbagai upaya telah dilakukan pemerintah dalam bidang pendidikan untuk meningkatkan kualitas SDM, seperti melakukan bermacam-macam perubahan serta pembaruan dalam bidang pendidikan agar sumber daya manusianya dapat bersaing dalam era globalisasi.

Berbagai jenis tes berskala internasional telah diikuti Indonesia. Salah satunya ialah dengan terlibat dalam Program for International Student Assessment (PISA). PISA merupakan studi internasional yang rutin dilakukan setiap tiga tahun sekali. Tujuan diselenggarakannya PISA yaitu untuk mengukur kemampuan siswa dan mengetahui kesiapan siswa dalam menghadapi tantangan dimasa depan. Sesuai dengan tujannya, PISA mengumpulkan berbagai informasi mengenai pengetahuan, latar belakang siswa, dan 
latar belakang sekolah untuk dijadikan rujukan atau sebagai pembanding untuk negara-negara peserta dalam membuat suatu kebijakan guna meningkatkan mutu pendidikan.PISA mengukur kemampuan literasi membaca, matematika, dan IPA untuk siswa yang berusia 15 tahun atau setara dengan siswa SMP. Dalam soal PISA terdapat 6 level kemampuan matematika, semakin tinggi level soal maka semakin sulit dalam memecahkan soal tersebut.

Literasi matematis atau melek matematika, menurut draft assessment framework PISA 2015 (OECD, 2017) adalah kemampuan seseorang untuk merumuskan, menerapkan dan menafsirkan matematika dalam berbagai konteks, termasuk kemampuan melakukan penalaran secara matematis dan menggunakan konsep, prosedur, dan fakta untuk menggambarkan, menjelaskan atau memperkirakan fenomena atau kejadian. Literasi matematis sangat berkaitan dengan dunia nyata, oleh karena itu dalam literasi matematis kita dituntut untuk memahami peranan matematika dalam kehidupan nyata dan menggunakannya dalam menyelesaikan masalah yang berhubungan dengan konteks kehidupan sehari-hari. Dalam hal-hal tertentu, peranan konsep, struktur, serta ide matematis digunakan sebagai alat untuk mengubah permasalahan dalam dunia nyata kedalam manipulasi simbol (Kusumah, 2011). Sejalan dengan hal tersebut, dalam literasi matematis juga dilibatkan kemampuan untuk mengubah (transform) permasalahan dari dunia nyata ke bentuk matematika atau justru sebaliknya, yaitu menafsirkan suatu hasil atau model matematika ke dalam permasalahan aslinya.

Siswa Indonesia selama 4 periode mengikuti PISA yaitu sejak tahun 2000 sampai 2009 hanya mampu menjawab pertanyaan PISA level 1, 2, 3, dan sedikit siswa yang dapat menyelesaikan pertanyaan level 4 (Edo, dkk., 2013). Berdasarkan hasil studi tersebut terlihat bahwa kebanyakan siswa Indonesia kesulitan dalam menyelesaikan soal literasi matematika pada level 4 sampai level 6. Soal-soal pada level tersebut sudah menuntut siswa untuk menggunakan kemampuan bernalarnya dalam menyelesaikan masalah-masalah yang kompleks atau non rutin. Selain itu, untuk menyelesaikan masalah pada level tersebut siswa harus mahir dalam menyatakan masalah dalam bentuk model matematika, memberikan argumen berdasarkan hasil yang diperoleh serta fakta yang ada. Hal itu mengisyaratkan bahwa kemampuan literasi matematis siswa Indonesia baru mencapai tahap pengoperasian matematika yang masih sederhana.

Masalah yang muncul tentang kesulitan siswa dalam mempelajari matematika adalah karena banyak siswa yang mengangap bahwa pelajaran matematika itu sulit, dan ada siswa yang beranggapan bahwa ia tidak berbakat dalam matematika. Sikap siswa yang se- 
perti ini akan membuat mereka kesulitan dalam menjalani kehidupannya, karena kompetensi matematis akan semakin berkembang dan semakin dibutuhkan di masa depan. Para siswa seharusnya memiliki sikap menghargai kegunaan matematika dalam kehidupan, yaitu memiliki rasa ingin tahu, perhatian, dan minat dalam mempelajari matematika, serta sikap ulet dan percaya diri.

Rendahnya kemampuan literasi matematis siswa diakibatkan proses pembelajaran di sekolah belum bisa memfasilitasi siswa untuk bisa berpikir secara optimal. Pada kenyataannya di lapangan, siswa hanya berperan sebagai penerima informasi sehingga pembelajaran yang dilakukan tidak bermakna.Kegiatan pembelajaran yang dilakukan di sekolah seharusnya dapat membuat siswa untuk aktif. Kemampuan guru mengatur proses belajar mengajar dengan baik, akan menciptakan situasi yang memungkinkan anak belajar, sehingga merupakan titik awal keberhasilan pengajaran (Djamarah \& Zain, 2006). Sehubungan dengan hal tersebut, diperlukan suatu perubahan dan variasi dalam mengajar matematika agar pembelajaran yang terpusat pada guru berubah menjadi terpusat pada siswa. Sesuai dengan pendapat Turmudi (2009), agar siswa bersikap positif terhadap matematika perlu ada strategi yang menarik bagi siswa, memotivasi mereka belajar, memberikan rasa aman untuk belajar, dan menyenangkan bagi mereka. Pemilihan metode pembelajaran harus disesuaikan dengan kondisi siswa, yang memungkinkan untuk menarik perhatian siswa dalam proses pembelajaran. Case (1996, dalam Samuelsson, 2010) berpendapat bahwa variasi metode pengajaran penting karena metode pengajaran yang berbeda akan menarik perhatian kompetensi dalam matematika.

Salah satu model pembelajaran yang dapat memfasilitasi siswa dalam mengembangkan literasi matematis yang menuntut siswa untuk memecahkan masalah yang melibatkan penalaran yaitu model pembelajaran Osborn. Alex Faickney Osborn mengembangkan teknik Brainstorming sebagai metode Creative Problem Solving. Pembelajaran matematika dengan model pembelajaran Osborn yang menggunakan teknik Brainstorming terdiri dari beberapa tahapan yaitu: 1) Tahap orentasi (pemberian informasi dan motivasi); 2) Tahap analisis; 3) Tahap hipotesis; 4) Tahap pengeraman; 5) Tahap sintesis; 6) Tahap verifikasi. Masalah-masalah yang diajukan dalam sesi Brainstorming akan membuat siswa belajar dalam memaknai suatu masalah, sehingga siswa dapat mendeskripsikan masalah tersebut dengan kata-katanya sendiri. Penerapan teknik Brainstorming menuntut siswa agar bisa mengkomunikasikan gagasannya dengan efektif. Jika siswa dapat menginterpretasikan masalah dan memberikan argumen terhadap masalah yang diberikan, maka kegiatan tersebut dapat memberikan pengaruh terhadap literasi matematis siswa. 
Kegiatan diskusi yang dilakukan saat sesi Brainstorming akan memunculkan banyak argumentasi yang berbeda-beda dalam memahami dan menemukan solusi dari permasalahan yang diberikan, sehingga siswa belajar untuk menghargai pendapat yang berbeda. Melalui kegiatan tersebut, diharapkan bisa menimbulkan rasa percaya diri pada siswa dan motivasi untuk mempelajari matematika. Hal ini akan meningkatkan kemampuan matematis siswa.

Berdasarkan uraian yang telah dikemukakan di atas, maka penelitian ini bertujuan untuk mengetahui peningkatan kemampuan literasi matematis siswa melalui model pembelajaran Osborn di sekolah menengah pertama.

\section{Metode Penelitian}

Penelitian ini merupakan penelitian kuasi eksperimen karena pemilihan sampel tidak secara random, tetapi menerima keadaan sampel apa adanya. Desain penelitian yang digunakan adalah kelompok kontrol non-ekuivalen. Populasi dalam penelitian ini adalah seluruh siswa kelas VIII SMPpadasebuah SMPdi Kota Cimahi. Dipilihnya kelas VIII sebagai populasi penelitian karena merujuk pada definisi OECD tentang literasi matematis, yang menyatakan bahwa tes literasi matematis dilakukan pada anak yang berusia 15 tahun atau setara siswa SMP kelas VIII. Pengambilan sampel dalam penelitian ini dilakukan dengan menggunakan teknik purposive sampling. Subjek dalam penelitian ini adalah siswa kelas VIII dan melibatkan 2 kelas untuk dijadikan sampel penelitian, yaitu kelas kontrol dan eksperimen. Kelompok eksperimen merupakan kelompok siswa yang mendapat pembelajaran dengan model pembelajaran Osborn dan kelompok kontrol adalah kelompok siswa yang mendapat pembelajaran ekspositori. Pembelajaran ekspositori dalam penelitian ini nmerupakan pembelajaran yang dilakukan dengan cara penyampaian materi secara verbal atau lisan, materi pembelajaran merupakan materi yang sudah jadi seperti data atau fakta, konsep-konsep tertentu yang harus dihapal.

Menurut Ruseffendi (2005:52) disain penelitian yang dapat digunakan adalah desain eksperimen. Adapun desainnya adalah sebagai berikut:

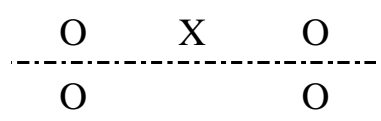

Keterangan :

O : Pretes atau Postes Literasi Matematis

$\mathrm{X}$ : Pembelajaran matematika yang menggunakan Model Pembelajaran Osborn

--- : Subjek tidak dikelompokkan secara acak 
Instrumen yang digunakan dalam penelitian ini adalah instrumen tes dan non-tes. Informasi tentang literasi matematis siswa sebelum dan sesudah pemberian perlakuan diperoleh melalui tes uraian, sedangkan untuk mengukur aktivitas siswa selama proses pembelajaran digunakan lembar observasi.

Teknik analisis data yang digunakan, yaitu untuk instrumen tes dianalisis dengan uji normalitas pada setiap data skor pretest, posttes, homogenitas, N-Gain ternormalisasi untuk tiap kelompok serta uji-t untuk menguji perbedaan rataan skor $N$-Gain.

\section{Hasil dan Pembahasan}

\subsection{Hasil Penelitian}

Hasil penelitian diperoleh dari analisis data tes awal, tes akhir, dan indeks gain (gain ternormalisasi). Pembahasan hasil penelitian ini berdasarkan pada faktor-faktor yang diamati dan ditemukan dalam penelitian. Analisis peningkatan literasi matematis melibatkan data pretes dan postes. Pretes dilakukan untuk mengetahui kemampuan awal siswa sebeum diberikan pembelajaran, sedangkan postes dilakukan untuk mengetahui kemampuan siswa setelah diberikan pembelajaran. Peningkatan literasi matematis siswa dilihat dari skor $\mathrm{N}$-gain setelah dilakukan pembelajaran. Berikut ini disajikan statistik deskriptif pretes, postes, dan gain ternormalisasi ( $N$-gain) pada kelas ekspositori dan kelas Osborn untuk literasi matematis.

Tabel 1. Statistik Deskriptif Literasi Matematis

\begin{tabular}{ccccccccccc}
\hline \multirow{2}{*}{ Nilai } & \multicolumn{4}{c}{ Kelas Osborn } & \multicolumn{6}{c}{ Kelas Ekspositori } \\
\cline { 2 - 11 } & $\mathbf{N}$ & $\mathbf{X}_{\text {min }}$ & $\mathbf{X}_{\text {maks }}$ & $\overline{\boldsymbol{x}}$ & $\mathbf{S D}$ & $\mathbf{N}$ & $\mathbf{X}_{\text {min }}$ & $\mathbf{X}_{\text {maks }}$ & $\overline{\boldsymbol{x}}$ & SD \\
\hline Pre-test & 35 & 1 & 7 & 2,54 & 1,46 & 35 & 1 & 5 & 2,34 & 1,11 \\
\hline Post-test & 35 & 6 & 13 & 9,11 & 1,53 & 35 & 5 & 11 & 7,26 & 1,63 \\
\hline N-gain & 35 & 0,18 & 0,43 & 0,30 & 0,06 & 35 & 0,10 & 0,38 & 0,22 & 0,07 \\
\hline \multicolumn{1}{c}{ Skor Maksimum Ideal = 24 } \\
\hline
\end{tabular}

Dari Tabel 1 terlihat rataan pretes untuk kelas Osborn dan kelas ekspositori tidak jauh berbeda. Hal ini menunjukkan bahwa kemampuan awal kedua kelas relatif sama, sedangkan rataan untuk postes menunjukkan kelas Osborn mengalami peningkatan yang signifikan dibandingkan dengan kelas ekspositori meskipun perbedaannya tidak terlalu jauh.

\subsubsection{Analisis Data Pretes Literasi Matematis}

Data yang digunakan untuk analisis selanjutnya adalah data pretes. Data pretes dikumpulkan dan dianalisis untuk mengetahui ada-tidaknya perbedaan kemampuan awal literasi 
matematis sebelum dilakukan pembelajaran. Dilakukan uji kesamaan rata-rata dua sampel dengan menggunakan ujistatistik non-parametrik Mann-Whitney, karena data pretes literasi matematis tidak berdistribusi normal dan homogen. Uji kesamaan rataan dilakukan untuk mengetahui ada tidaknya perbedaan yang signifikan untuk kemampuan awal literasi matematis.

Tabel 2. Uji Kesamaan Dua Rataan Data Pretes Literasi Matematis

\begin{tabular}{ccc}
\hline Mann-Whitney $U$ & $\mathbf{Z}$ & $\begin{array}{c}\text { Asymp. Sig. } \\
\text { (2-tailed) }\end{array}$ \\
\hline 589,000 & $-0,288$ & 0,773 \\
\hline
\end{tabular}

Berdasarkan Tabel 2 di atas, terlihat nilai signifikansi 0,773 lebih dari 0,05, sehingga $\mathrm{H}_{0}$ diterima. Maka kemampuan awal literasi matematis antara kelas ekspositori dan kelas Osborn tidak berbeda secara signifikan. Berdasarkan hal tersebut, maka dapat disimpulkan sebelum mendapatkan pembelajaran siswa kelas Osborn dan kelas ekspositori memiliki kemampuan awal yang sama.

\subsubsection{Analisis Data PostesLiterasi Matematis}

Data postes dikumpulkan dan dianalisis untuk mengetahui ada tidaknya perbedaan peningkatan literasi matematis setelah dilakukan pembelajaran. Data postes literasi matematis tidak memenuhi uji kenormalan, maka dilanjutkan dengan ujistatistik non-parametrik Mann-Whitney. Uji perbedaan rataan dilakukan untuk mengetahui ada tidaknya perbedaan yang signifikan untuk kemampuan literasi matematis antara kelas Osborn dan kelas ekspositori.

Tabel 3. Uji Perbedaan Dua Rataan Data Postes Literasi Matematis

\begin{tabular}{cccc}
\hline Mann-Whitney $U$ & $\mathrm{Z}$ & $\begin{array}{c}\text { Asymp. Sig. } \\
\text { (2-tailed) }\end{array}$ & $\begin{array}{c}\text { Asymp. Sig. } \\
\text { (1-tailed) }\end{array}$ \\
\hline 256,500 & $-4,243$ & 0,000 & 0,000 \\
\hline
\end{tabular}

Berdasarkan Tabel 3 di atas, terlihat nilai signifikansi satu pihak ( 1 -tailed) yaitu sebesar 0,000 lebih kecil dari 0,05, sehingga $\mathrm{H}_{0}$ ditolak. Maka literasi matematis kelas Osborn secara signifikan lebih baik dari kelas ekspositori. Berdasarkan hal tersebut, maka dapat disimpulkan setelah mendapatkan pembelajaran, literasi matematis siswa kelas Osborn lebih baik dari kelas ekspositori.

\subsubsection{Analisis Skor N-gain Kemampuan Literasi Matematis}

Analisis data gain dilakukan untuk mengetahui peningkatan literasi matematis siswa setelah dilakukan pembelajaran. Dalam menganalisis data gain ini, melibatkan data 
pretes dan postes. Berikut hasil rataan skor n-gain yang disajikan pada Tabel 4.

Tabel 4. Rataan Skor N-Gain dan Klasifikasinya

\begin{tabular}{ccc}
\hline Kelas & $\overline{\boldsymbol{x}}$ & Klasifikasi \\
\hline Osborn & 0,30 & Sedang \\
\hline Ekspositori & 0,22 & Rendah \\
\hline
\end{tabular}

Tabel di atas memperlihatkan rataan skor n-gain kelas Osborn dan kelas ekspositori. Nilai rataan tersebut akan diuji lebih lanjut untuk melihat apakah ada perbedaan yang signifikan rerata skor n-gain kelas Osborn dan kelas ekspositori. Dilakukan uji perbedaan rataan skor $n$-gain dengan menggunakan uji-t, karena berdistribusi normal dan homogen.

Hasil uji perbedaan dua rataan $n$-gain literasi matematis berdasarkan pendekatan pembelajaran dengan menggunakan uji-t dapat dilihat pada Tabel 5 di bawah ini.

Tabel 5. Uji Perbedaan Dua Rataan Data N-Gain Literasi Matematis

\begin{tabular}{cccc}
\hline \multicolumn{4}{c}{ t-test for Equality of Means } \\
\hline $\boldsymbol{t}$ & $\boldsymbol{d} \boldsymbol{f}$ & Sig. (2-tailed) & Sig. (1-tailed) \\
5,000 & 68 & 0,000 & 0,000 \\
\hline
\end{tabular}

Hasil uji perbedaan dua rataan data n-gain berdasarkan Tabel 5 di atas, menunjukkan bahwa nilai signifikansi satu pihak (1-tailed) yaitu sebesar 0,000 lebih kecil dari 0,05, sehingga $\mathrm{H}_{0}$ ditolak. Artinya, rataan skor n-gain kelas Osborn secara signifikan lebih baik dari rataan skor n-gain kelas ekspositori. Dapat disimpulkan, peningkatan literasi matematis pada siswa yang mendapat model pembelajaran Osborn lebih baik dibandingkan dengan siswa yang mendapat pembelajaran ekspositori.

\subsection{Pembahasan}

Perbedaan peningkatan kemampuan siswa yang mendapat pembelajaran ekspositori dengan siswa yang mendapat model pembelajaran Osborn, memperlihatkan bahwa kegiatan yang dilakukan saat pembelajaran mempunyai karakteristik yang berbeda. Model pembelajaran Osborn dimulai dengan pemberian masalah, masalah-masalah yang diberikan merupakan masalah kontekstual sesuai dengan literasi matematis yang berhubungan dengan konteks dunia nyata. Sesuai dengan pendapat Novita, dkk. (2012) bahwapertanyaan-pertanyaan yang dikembangkan selain menantang (non-rutin) juga harus mencerminkan masalah yang biasa dihadapi oleh siswa dalam kehidupan sehari-hari untuk memberikan kesempatan bagi siswa untuk menerapkan pengetahuan matematismereka. Masalah yang diajukan, disesuaikan dengan tujuan pembelajaran agar tujuan 
pembelajaran dapat tercapai. Pemberian masalah kepada siswa akan menimbulkan konflik kognitif, dalam konflik kognitif, siswa akan memanfaatkan kemampuan kognitifnya dalam upaya justifikasi, konfirmasi atau verifikasi terhadap pendapatnya (Ismaimuza, 2010). Dengan adanya konflik tersebut, siswa akan berusaha memaknai masalah, berpikir dan berusaha dengan menggunakan konsep-konsep yang ia ketahui untuk menemukan penyelesaian dari masalah tersebut. Dalam hal ini, siswa diharapkan dapat mengembangkan strategi untuk menyelesaikan masalah. Ketika siswa merasa kesulitan atau mengalami kebuntuan, maka peran guru sebagi fasilitator akan memberikan arahan dan bantuan kepada siswa melalui intervensi-intervensi. Selain itu, peran teman dalam kelompok akan membantu siswa yang kesulitan, mereka dapat berdiskusi dan bekerjasama untuk menemukan solusi pemecahan masalah.

Kegiatan pembelajaran dengan model Osborn memungkinkan siswa untuk mengeluarkan pendapatnya secara bebas, karena pada pembelajaran ini ide yang keluar tidak akan dikritik dahulu. Sehingga ide-ide yang keluar dari siswa dapat mengalir dengan bebas. Ide yang keluar dari tiap siswa akan ditampung pada tiap-tiap kelompok, sehingga siswa akan dilatih untuk menyampaikan pendapat. Melalui kegiatan ini siswa akan memiliki kemampuan untuk berkomunikasi, yaitu dalam hal mengkomunikasikan gagasannya. Siswa juga akan dilatih untuk menerima pendapat yang berbeda. Kegiatan pembelajaran yang dilakukan berlangsung secara interaktif dan dinamis, siswa diminta untuk menjelaskan ide penyelesaian masalah yang diberikan serta menyampaikan alasannya, menyampaikan keberatannya terhadap ide yang dianggap tidak sesuai, dan bersama-sama mencari solusi yang tepat untuk menyelesaikan masalah yang diberikan. Sehingga siswa dapat memaknai masalah yang diberikan dan mengkonstruksi pengetahuannya dalam memahami materi. Kegiatan tersebut tentu berbeda dengan kegiatan pembelajaran ekspositori yang secara umum berpusat pada guru. Pembelajaran matematika yang melalui latihan buku teks dan terpusat pada guru akan menyebabkan siswakesulitan untuk menggunakan matematika dalam diskusi terbuka, terapan, atau berbasis situasi (Samuelsson, 2010).

Kesulitan guru dalam kegiatan pembelajaran yang menggunakan model pembelajaran Osborn adalah ketika siswa mengalami kesulitan dalam menemukan solusi pemecahan masalah, terlebih apabila siswa mengalami kebuntuan. Hal ini yang dapat menyebabkan pembelajaran tidak efektif. Oleh karena itu, pemberian intervensi pada bahan ajar harus mendorong dan mengarahkan siswa agar tidak mengalami kebuntuan. Persiapan dalam membuat bahan ajar harus dilakukan dengan matang agar dapat memi- 
nimalisir kebuntuan pada siswa. Meskipun pembelajaran dilakukan secara berkelompok, tetapi guru memiliki peranan yang sangat penting sebagai pengatur jalannya diskusi. Kolaborasi yang baik antara bahan ajar, guru, dan siswa saat pembelajaran merupakan faktor penentu dalam meningkatkan literasi matematis siswa.

Beberapa aspek yang berkaitan dengan literasi matematis dilatih saat pembelajaran berlangsung dengan model Osborn. Tahap analisis saat kegiatan pembelajaran dengan model pembelajaran Osborn dapat melatih siswa dalam mengidentifikasi fakta-fakta dasar yang ditentukan dalam soal.Siswa diberikan kesempatan untuk bisa merancang sendiri strategi pemecahan masalah pada tahap pengeraman, dan dilatih untuk bisa mengkomunikasikan gagasannya serta menyampaikan argumentasinya pada tahap sintesis. Rangkaian tahapan kegiatan siswa saat pembelajaran dengan model pembelajaran Osborn menjadi salah satu faktor yang mengakibatkan peningkatan literasi matematis siswa yang mendapatkan model pembelajaran Osborn lebih baik dibandingkan dengan kelas yang mendapatkan pembelajaran ekspositori.

\section{Kesimpulan}

Berdasarkan hasil analisis data dan temuan yang telah dijelaskan pada bagian terdahulu, dapat diambil beberapa kesimpulan yang berkaitan dengan faktor pembelajaran dan literasi matematis. Kesimpulan-kesimpulan tersebut yaitu, peningkatan literasi matematis pada siswa yang memperoleh model pembelajaran Osborn lebih baik dibandingkan dengan siswa yang memperoleh pembelajaran ekspositori.

Hasil dalam penelitian menunjukkan literasi matematis siswa yang diajarkan dengan menggunakan model pembelajaran Osborn lebih baik dari pembelajaran ekspositori. Dengan demikian, hasil penelitian ini berimplikasi terhadap pemilihan model pembelajaran oleh guru matematika di sekolah.

\section{Ucapan Terimakasih}

Penulis menyadari bahwa dalam penulisan artikel ini banyak mendapatkan bantuan dan pertolongan dari berbagai pihak. Oleh karena itu, dengan segala kerendahan hati, penulis menyampaikan ucapan terimakasih yang tulus kepada: Bapak Drs. Usep Dedi Suhendra dan Ibu Neni, S.Pd., selaku Kepala Sekolah dan guru SMP Pasundan 3 Cimahi yang telah memberikan izin untuk melakukan penelitian. Keluarga dan teman sejawatyang telah memberikan motivasi dan bantuan dalam menyelesaikan penulisan artikel. 


\section{Daftar Pustaka}

Djamarah, S dan Zain, A. (2006). Strategi Belajar Mengajar Edisi Revisi. Jakarta: Rineka Cipta.

Edo, S. I., Hartono, Y., \& Putri, R. I. I. (2013). Investigating Secondary School Students' Difficulties in Modeling Problems PISA-Model Level 5 And 6. IndoMS, Journal of Mathematics Education, 4(1), 41-58.

Ismaimuza, D. (2010). Kemampuan Berpikir Kritis dan Kreatif Matematis Siswa SMP Melalui Pembelajaran Berbasis Masalah dengan Strategi Konflik Kognitif. SPS UPI Bandung.

Kusumah, Y. S. (2011). 1st International Symposium on Mathematics Education Innovation ( ISMEI ). MATHEMATICAL LITERACY, 45-52. Yogyakarta.

Novita, R., Zulkardi., \& Hartono, Y. (2012). Exploring Primary Student's Problem-Solving Ability by Doing Tasks Like PISA's Question. IndoMS, Journal of Mathematics Education, 3(2), 133-150.

OECD. (2017). PISA 2015 Assesment and Analytical Framework: Science, Reading, Mathematic, Financial Literacy and Collaborative Problem Solving. Retrieved from https://doi.org/10.1787/9789264281820-en.

Ruseffendi, E. T. (2005). Dasar-dasar Penelitian Pendidikan dan Bidang Non-eksakta Lainnya. Bandung: Tarsito.

Samuelsson, J. (2010). The Impact of Teaching Approaches on Students' Mathematical Proficiency in Sweden. International Electronic Journal Of Mathematics Education, $5(2)$.

Turmudi. (2009). Landasan Filosofis dan Teoritis Pembelajaran Matematika (Berparadigma Eksploratif dan Investigatif). Jakarta: Leuser Cita Pustaka. 